\title{
15. Duel-Names: How toponyms (placenames) can represent hegemonic histories and alternative narratives $^{1}$
}

\author{
Laura Kostanski \\ Federation University Australia
}

\section{Introduction}

Of central import to this study is the rarely cited notion that it is not spaces which ground identifications, but places. How then does space become place? By being named' (Carter, Donald and Squires 1993: xii). Carter and others are among the few who have overtly linked the process of naming to the creation of places from space and their theoretical cohort include Claude Levi-Strauss (1962) who noted that place is named space, and Tim Cresswell (2004: 10) who asserted that 'when humans invest meaning in a portion of space and then become attached to it in some way (naming is one such way) it becomes place'. This concept of place positioning human landscape interactions is of integral importance to this research in that it is thought to be toponyms which symbolise this interaction and identification. This paper contributes to the developing field of cultural toponymy by examining whether the social and cultural role of toponyms can be partly defined through a theory on toponymic identity. Essentially, this paper asks 'can toponyms contribute to social, cultural and historical identity formation or recognition in similar, yet distinguishable, ways to places?'.

The impetus for this research came about as a result of the Victorian State Government's proposal in 1989 to remove colonially-allocated toponyms for features in the Grampians National Park (as it was then officially recorded in the Victorian State Register of Place Names) and restore Indigenous names. Within geographical literature it is asserted that recognition of Indigenous and non-Indigenous places gives inhabitants a stronger sense of identity (Taylor

\footnotetext{
1 The title of the paper was inspired by the happenstance occurrence of a transcriber returning some of the interview manuscripts with the phrase 'duel-name' utilised instead of the correct 'dual-name' where the participants or researcher were discussing the official recognition of two names for one place. It was evident that the transcribers were translating what they heard into the written word, and not being familiar with the concept of dual-naming, and hearing the tones of the interview discussions, must have assumed that duelnaming referred to a process of contesting a name for a place.
} 
1992; Wong 2002). Indeed, one of the general arguments used by government agencies (including the United Nations Group of Experts on Geographical Names) for following the process of reinstating Indigenous toponyms in the landscape is that the names will help reassert Indigenous identity and aid in recognising the Indigenous connections to the landscape (UNGEGN Working Group on the Promotion of Indigenous and Minority Group Place Names 2007). Yet there is currently not enough research nor theories published on the determinants of toponymic identity to support these arguments. The purpose of this paper is therefore to fill this gap in knowledge regarding toponymic identity.

If governments are to talk of reinstating Indigenous toponyms as a nexus from which to provide more tenable identification with the landscape for both Indigenous and non-Indigenous people, then this paper aims to explore and build a strong theoretical framework upon which to base these assertions. This paper will firstly summarise details regarding the case study, data collection and participant identification methods before providing an outline of the theoretical background underpinning the research. The discussion will then move into an analysis of the key themes of the case study data in relation to the existing literature on place identity, before finally offering a summary of the results and explanation of the proposed theory of toponymic identity.

\section{Case study}

\subsection{Background to case study and methods}

The Grampians (Gariwerd) National Park covers 170,000 hectares containing ancient mountains, rocky escarpments and Indigenous rock art. The area is popular with tourists for mountain walking, rock climbing and learning about Indigenous art and cultural heritage, whilst the area around the park is populated by farming and tourism-based communities.

The traditional custodians of this landscape are the Jardwadjali and Djabwurrung peoples, whose traditional boundaries dissect the area. The Djabwurrung and Jardwadjali peoples have names for sites and areas within the contemporary National Park area, with one of the mountain ranges known as Gariwerd.

In 1836 Thomas Mitchell, then Surveyor Mitchell named the area after a place in his home country of Scotland, where the name Grampians is used to refer to a range of mountains. The mountains were originally referred to as Mons Graupius, the meaning of which is unknown, except for the fact that 'mons' refers to 'mountain' (Fraser 2005: 66). 
As the landscape is a mental construct, Richard Baker (1999: 33) argues that we must see it as a cultural construct, and should thus observe it as the physical form of social and political ideologies. Mitchell's seemingly simple act of place-naming at once transferred the legal and cultural identity of the landscape from Indigenous possession and understanding to colonial possession and control. From 1836 onwards the European names defined by Mitchell and the colonists who followed him, became the official government records of the landscape. Maps, addresses, electorates and government zones all came to identify with the area as Grampians in essence. The Jardwadjali and Djabwurrung were dispossessed from official records by an act of toponymy. In the Grampians (Gariwerd) area, this lessening of status began in 1836 and predominated until 1989, when the Victorian Government announced its intention to restore the Indigenous names within the National Park.

\subsection{The 1989-1990 name restoration debate}

In March 1989 the Hon. Steve Crabb, Minister for Tourism with the Victorian Labor Government, introduced the process of Indigenous toponym restoration in the National Park. Steve Crabb agreed to be interviewed for this research and when asked why he had started this process, he stated that there were two reasons. The first, which is relevant to the focus of this paper, pertained to the idea that

one of my experiences of having sort of tramped around the Grampians was that one of the most fascinating things about it was the Aboriginal heritage that was there ... there was a whole lot of quite mystical stuff there that wasn't there, it wasn't very well interpreted and a lot of the time there were wire cages around it or it was hidden because they didn't want people to know it was there and none of the rest of the Grampians reflected it so there was ... stuff with silly names ... like "Elephant's Hide"... (Crabb, Steve, interview 2006)

In essence, Steve Crabb's proposal to restore the Indigenous names came from his desire to 'correct' what he perceived to be the historical 'wrongs' of removing Indigenous toponyms from the landscape. [His second reason - a desire to promote tourism - is discussed in (Kostanski 2009).]

At the time of Steve Crabb's proposal to investigate the traditional Indigenous names for the National Park area, the government regulations which guided naming practices in the State of Victoria, stipulated that there was only the possibility of having 'one place and one name'. The implications of this regulation meant that for the Indigenous toponyms to be restored, the colonial toponyms would have to be removed, and therein the problem and the fuel for public reaction lay. This regulation and its implicit notion that the restoration 
of Indigenous toponyms could only be enacted with the removal of existing, predominantly Anglo-Celtic, toponyms was the catalyst for overwhelming political and community reaction to the proposals.

The 12 months following the original proposal saw continued public and political debate, mostly negative in substance. The most informative of the reactions to the changes were those from individual members of the community. These responses were recorded as letters to the editors of rural and metropolitan newspapers, and as signatures on petitions during the debate. The letters were both supportive and negative, and their contents highlighted the key concerns the community had about the research and the proposal to restore Indigenous toponyms.

\subsection{Methods and participants}

In total 141 letters and 94 newspaper reports or editorials were collated for the purposes of this research. In addition, 114 participants in the original debate were sent questionnaires, of which 48 were returned. Further to this, 45 people were interviewed for this research program between October and November 2006. The interviews involved asking the participants open-ended questions, which related to their sense of place and toponym.

In this paper where a name appears by itself, such as 'Doug' or 'Anita' this is a pseudonym used to identify oral-history and/or interview participants. Where a name appears with a surname, and is not followed by a reference indicating that it is a quote taken from a media source, this is the real name of an oral-history and/or interview participant who explicitly gave permission for their real name to be used because of their political or key stakeholder role in the initial name restoration program.

\section{Theoretical background}

Toponyms are, by their very description, names for places. As such, this paper explores human interactions with places and their names through theories related to place and place attachment, as will now be discussed. The focus here is on place itself, as the research of this paper centres on place names.

\subsection{Sense of place and place attachment}

Many geographical and psychological researchers have developed their own sense of place theories over the past 40 years, and often there is criticism within the literature (Patterson and Williams 2005; Pretty, Chipuer and Bramston 2003: 274) of the lack of a distinct theory being a hindrance to the progression of 
the study. Nonetheless, to create a structured basis for this research the study of 'sense of place' has been designated as the overarching study of 'place attachment' and 'place interference', with place attachment consisting of 'place identity' and 'place dependence'. This grouping has been determined based on recent research by various geographers (Hidalgo and Hernandez 2001; Jorgensen and Stedman 2006; Williams and Vaske 2003; Shamai 1991).

Shamai (1991: 347) asserts that sense of place is an umbrella concept that includes other concepts such as place attachment, national identity and regional awareness. Hidalgo and Hernandez (2001: 274) assert that a general description of place attachment defines it as 'an affective bond or link between people and specific places'. They posit that place attachment takes two forms: emotional and physical (Hidalgo and Hernandez 2001: 279). Jorgensen and Stedman (2006: 316) note that place attachment is a concept that can be included under the term 'sense of place', along with the constructs of place identity and place dependence. These two terms identity and dependence are similar to Hidalgo and Hernandez' social and physical, and considering recent literature by Williams and Vaske (2003) and since then others (Sharpe and Ewert 2000; White, Virden and van Riper 2008) this paper will defer to the terms identity and dependence. Williams and Vaske (2003) also classify place attachment under the term 'sense of place', but go further than Jorgensen and Stedman and state that identity and dependence are correlated concepts which are sub-constructs of place attachment.

Some theorists note that place attachment, identity and dependence (along with sense of community) are separate but related concepts (Pretty et al. 2003) whilst others state that place dependence and identity are models of person-place relationships (Shumaker and Taylor 1983). During the research phase of this program the most convincing theoretical assertion was promoted by Williams and Vaske (2003) who stated that place identity and dependence were constructs of place attachment. Williams and Vaske (2004: 5) assert that there are two different forms of attachment to place. The first they label 'place dependence' and describe it as a functional attachment to place which 'reflects the importance of a place in providing features and conditions that support specific goals or desired activities' and also 'suggests an ongoing relationship with a particular setting'. The second form of attachment to place Williams and Vaske label 'place identity', which they assert is an emotional attachment to place. Further, they posit that place identity 'generally involves a psychological investment with the place that tends to develop over time'. In addition to this is the theory that place identity does not have to result from particular experiences with the place, yet place identity 'enhances self-esteem ... increases feelings of belonging to one's community ... and is an important component of communications about environmental values and policies'. Thus, Williams and Vaske defined place 
attachment as occurring in two distinguishable forms, that of the emotional and that of the functional. [The focus for this paper is the emotional attachment, discussion of the functional attachment can be found in (Kostanski 2009).]

\subsection{Place identity}

For Sharpe and Ewert (2000: 218) the term place identity is a second component of place attachment, which is linked to 'the emotional and symbolic nature of person-place relationships'. This theme of the emotional nature of person-place interactions is explored by Proshansky (1978) who determined that place identity is a subconcept of self-identity. Hernandez and others (2007: 311) concur with this notion of place identity being a component of personal identity and Twigger-Ross and Uzzel (1996: 210) expanded upon Proshansky's notion of place identity to claim that it is 'not a separate part of identity concerned with place, but that all aspects of identity have place-related implications to a greater or lesser extent'. Thus, the literature allows that personal identity is intrinsically linked to place identity, as part of a larger emotional or cognitive experience of sense of place.

As place identity is intrinsically linked to personal identity, many theorists note that official and local recognition of personal and collective forms of identity and attachment is extremely important. Taylor (1992: 32) asserted that 'recognition by others of the person one is, is central to having a meaningful life'. It can be argued that in instances such as the study area, where the government proposed to remove non-Indigenous names, the negative sentiment from some sectors of the community was borne out through anxiety of their identity being ignored and a perception that their identity was unimportant. Whether the theories of place identity can be extrapolated to explain people's emotional links to toponyms will now be explored.

\section{Components of place and toponymic identity}

From the literature review, and initial analysis of the data, it can be said that the construct of place identity is composed of four key elements: history/memory, community, emotions and actions/events. Thus, this section of the paper will explore these four key components individually, giving consideration to the discussion of place identity, and questioning in each instance whether similar identification with toponyms can be found in the research data. 


\subsection{History and memory}

First, we should explore why history and memory are considered to be components of place identity, and by extension toponymic identity. Lowenthal states that 'remembering the past is crucial for our sense of identity ... to know what we are confirms that we are' (1997: 197). Further, Hoelscher and Alderman (2004: 347) have theorised that 'together, memory and place conjoin to produce much of the context for modern identities'. Abrahamson notes that communities occupy their own geographical areas with which they become intimately associated. He argues that through this process of identification 'areas acquire symbolic qualities that include their place names and social histories' (Abrahamson 1996 cited in Ramsay 2003). As the literature asserts that place identity is partly formed through history and memory, it needs to be ascertained whether toponymic identity can also be formed through history and memory. An analysis of the research data in regards to participants' linking of history and memory to the toponyms can shed light on whether this phenomenon exists.

Furniss (2001: 284) has noted that with colonial histories, such as that promoted until the late twentieth century in Australia, an 'imagined linearity' of themes is deployed by the constant referral to 'discovery', to 'firsts' and to 'pioneers'. This referral to discovery and pioneers was notable in the research data, especially from those who opposed the renaming proposal. For example, Digby Crozier (1989), former member of parliament for the Liberal Party (in opposition at the time), asserted in his letter to the editor that the naming proposal was an 'assault on our history and the enduring links with the countries of origin of our pioneering forebears ... these names evoke an undoubted affinity'. He explicitly linked the use of non-Indigenous names with the history of the places as he knew and understood them. For Crozier, identity is linked to the toponym which represents and connects him to the history he knows of the case study area.

There were many others like Crozier who asserted similar sentiments. For instance, Vivian Day (1990: 2) wrote 'I think this is a cause worth fighting for, to uphold the respect of the pioneers and the likes of Major Mitchell and his party, who risked their lives to explore and name such a beautiful spot in which to live'. Further to this were the words of J. Atchison, a representative of the Australian Council of Scottish Clans, which intimated that the 'section of the community which descended from the Scottish pioneers and settlers ... [were] concerned to see their history and heritage under threat' (Editor 1989). The inference by Day and Atchison is that by removing the non-Indigenous names the links to colonial history would be lost and would be a sign of disrespect for their toponymic identity which hinged on notions of colonial exploration and settlement in the case study area. 
Tuan (1991: 688) has noted that 'normally only a socio-political revolution would bring about a change of name ... the new name itself has the power to wipe out the past and call forth the new'. In addition to the sentiments of Day and Atchison were arguments that removing the non-Indigenous names would be akin to removing colonial history from the landscape, map and community. These remarks can be contextualised in regards to the theory of Crane (1997: 1372) who posits 'that the future might mourn is the projection of nostalgia; it is also the supposition of historical thinking, which charges itself with the preservation of what would be lost both mentally and materially'. For most it is important to pass down historical meaning through the names for places with which they identify. In this manner, where previously it has been argued that it is place identity which helps to connect a population with their history, it can be seen that it is toponymic identity which also connects a population with their history.

It is argued by Furniss (2001: 285) that the imagined linearity of colonial history erases 'any prior Indigenous history, suggesting instead that the land and its inhabitants somehow did not exist, or their existence was unimportant, until they were "found" and incorporated into Western systems of knowledge'. Similarly, Lewicka (2008: 213) notes that 'events that happened before the group settled down in a place are assigned less significance and are less frequently recalled than events that are a part of the group past'. Sentiments of the nonexistence of Indigenous history, or unimportance of Indigenous history, to the case study area were often borne out in the letters. For example, Anne Pietsch (1990a: 12) asserted that 'Aboriginals never lived in the Grampians. They only visited and hunted there as they preferred the open spaces'. Further to this, Eric Beale wrote that

what is important is that the mountains were named in 1836 as the Grampians and that is what they have been known as here and all over the world for the last 150 years. As for Crabb's crazy statement that "the white man wiped out thousands of years of civilisation" I simply ask what civilisation? Does anybody know what he is talking about? Does he know himself? (Beale 1989)

The promotion of colonial history is necessarily one which is biased in favour of the mainstream society at the time. Thus, it can be asserted that Beale, and others of a similar sentiment, formed a toponymic identity similar to place identity, through the linking of history to the toponym.

Withers (2000: 534) has noted that with the creation and perpetuation of colonial history and the inevitable production of colonial maps as a technique with which to acquire and possess the landscape, 'natives were either "mapped out" of their own spaces or falsely "mapped in". In those terms, matters of authority ... become questions of authenticity: who, if not "the native voice", 
can give definitive orthographies and meanings to names?'. The question of authenticity for the Indigenous names was a common theme in the research data. J. Fitzsimmons (1989: 12) asserted in one letter that 'there is some question as to the validity of any Aboriginal place name recommendations ... this is based on the claim there are no true descendents of the Grampians' original inhabitants left'. For Fitzsimmons, being connected to a name meant that the descendents who gave the name had to still be in constant connection with the landscape. Further to this was the statement by F.R. Churton (1990: 59) that 'Aboriginals had no alphabet nor written records. How then can anyone give a correct name and spelling of so-called Aboriginal place names?' It was common in the data for participants to question the validity of the names, and this was summed up eloquently by Ern Golding (1990) in his letter, where he stated that 'Old "Mulga" would have been the only person with an understanding of the names, true meanings, if there are any ... he stated he was "the last full blooded aborigine in Victoria"'. For Churton and Golding an ignorance of colonial translation and transcription processes whereby colonists recorded Indigenous words in official records and other now-historical manuscripts, meant a questioning of the veracity of the proposed names. It can be contended for this colonially biased perception of landscape connection, not to mention the ignorance of the existence of an ongoing Indigenous presence in the area, that Fitzsimmons', Churton's and Golding's toponymic identity related strongly to a colonially-verifiable historical connection.

Cr Robert LoRicco (1989b) of the Shire of Stawell, noted that the reinstatement of Indigenous names would recognise the Indigenous history and rights to land recognition. Indeed, LoRicco was insistent that the reinstatement of the Indigenous names would reassert Indigenous identity in the study area:

European settlement has lasted only some 200 years but there has been an Aboriginal presence of some 17 to 20,000 years. The Aboriginal people now have the opportunity to re-establish and re-assert their cultural heritage and we should assist this process. ('Grampians name change debate', The Colac Herald, 2 June 1989: 7)

The councillor is discussing the notion that the reinstatement of the names is linked to respecting land tenure and Indigenous identity. Thus, for this councillor the notion of place and name are inextricably linked, the toponym is a symbol of the history of a place and current attempts should be made to help change this situation.

The perceived need to identify with colonial history and names, or to assert the suitability of Indigenous names, saw the narratives associated with identity diverge according to the memories that people associated with the names. The proposition is clear here that a toponym can be a symbol of multiple identities, 
and the use of two toponyms for one place can be a strong reminder of the multiple place histories and cultural identities which exist for a locale. At this point in the discussion attention needs to be given to notions of how collective or community cultures influence the creation and interpretation of place, and perhaps toponymic, identity.

\subsection{Community}

The presence or non-existence of Indigenous people in Australia and the region was a consistent 'fact' mentioned many times by various research participants. The minority status of Indigenous Australians was often used as support for the arguments of why colonial history and community connectedness was more important than Indigenous history. Clive Johnson (1990: 17) in his letter was able to recognise that Indigenous histories exist, but he was not willing to acknowledge them further than they had been already. He asserted that 'I don't for one minute deny Aborigines their place in history, but there is already an abundance of Aboriginal place names across Australia, far in excess of their percentage of the population'. Importantly, R. Pietsch (1990b: 10) questioned whether the community, as she perceived it, was going to 'have to become a radical minority group to be heard?'.

George Seddon(1997: 15) theorised that the words of the landscape carry 'cultural baggage' that may 'imply values and endorse power relations'. For Johnson and Pietsch the values of their community, as they understood them, had colonial interpretations as mainstream accepted notions of identity. Jackson (1989: 151) asserts that 'racism in Britain and similar societies is a dominant ideology ... racism refers to a set of ideas and beliefs that have the weight of authority behind them; they are enshrined in statutes and institutionalised in policy and practice'. The fact that predominantly non-Indigenous names were present in the landscape served to reinforce these notions of local, and by extension national, identity being that created by colonists and perpetuated by their descendents. This community identity was therefore bound to, and represented by, the toponyms. Penrose and Jackson (1994: 206) assert that 'Aboriginal land claims challenge the apparent "neutrality" of the hegemonic culture' and it could be extended here to assert that the proposal to reinstate Indigenous names was a challenge to the mainstream, colonially-defined local and national culture. As stated by Graham in an oral history interview, 'we really thought it was a whole lot of hogwash because to us there were the Grampians, had always been the Grampians and everybody that we, you know, talked to or associate with referred to them as the Grampians'. Graham's community was those whose identity was formed with the name Grampians, and he was asserting therefore that it was in the interest of community that the name Grampians be retained. 
For those who supported the renaming proposals they reported that recognising the Indigenous names for the places would lead to the conferral of a greater sense of Indigenous identity. For instance, Bruce Henry (1990: 10) noted that 'the real opposition to the proposed name changes comes from white Australia's ongoing refusal to recognise Aboriginal prior ownership ... the renaming of the Grampians ... serves to recognise this ownership'. Similarly, Louise in her interview asserted that while she didn't personally think the reinstatement of Indigenous names was important, 'I imagine the Indigenous people ... feel having their original names back would make them belong to the country more again'.

For those opposed to the proposal, many acknowledged an ignorance or nonacceptance that Indigenous people are part of the community. For example, C. and D. Hey (1990: 37) wrote in a letter that 'we were raised in the Grampians area and did not see any Aboriginals in the district until recently ... where are these people from?'. K.W. Dadswell (1989) asserted that 'the people of the area will ALWAYS cherish and call the range "the Grampians"'. Similarly, M. Albrecht (1990: 18) argued that 'it is our heritage and not his [Steve Crabb's] to toy around with. The Grampians forever!'.

Pretty and others assert that "discursive evidence that a place has become integrated into one's self-identity is re-enacted in " $\mathrm{I}$ " and "me" statements regarding the place'. Likewise, it can be argued that for statements such as those from the Heys and Albrecht, that the use of 'we' and 'our' denote an affinity they feel with the community around themselves. This community of 'our' and 'we' is that which rejects the renaming proposals and identifies with a colonial heritage. In this sense, it can be seen that toponymic identity does exist, and is reinforced by connection to community. Indeed, Wong (2002: 454) posits that 'a key source of [identity] beliefs is the culture(s) or community(ies) in which a person is located', and similarly it can be contended that a source of identity are the toponyms recognised by the community.

The notions of inclusion and exclusion, or insiders and outsiders, are fundamental to an understanding of community and national identity. Don Johns asserted in his interview that 'since then [1836], everyone has known it as the Grampians, worldwide. Now, why change the name? I mean, its rubbish in my opinion. ... I'm not a racist but I think what we're doing sometimes is like kow-towing to them and so forth, we're dividing'. Johns notes here that by 'everyone' knowing the area as the Grampians, the normal attitude is to accept that the community identity is that which is represented by the colonial names. As discussed by Salecl (1993: 102) 'national identification with "our kind" is based on the fantasy of an enemy, an alien who ... threatens us with habits, discourse and rituals which are not "our kind"". This was exposed in the interview with Doug who asserted that 
they [the government] should have kept Grampians and underneath if they wanted in brackets put Gariwerd because it's the Caucasian people's taxes that are paying for the running and the maintaining and keeping the Grampians afore and they are the most populated, the majority of the population. It's not that we have a thing set against that but to completely take history and completely change it to something that noone refers to, or relates to, or understands... (Doug, interview, 2006)

It can be seen in Doug's narrative that he perceives the non-Indigenous population to have credentials for deciding which names will be used in the landscape. Interestingly, Salecl (1993: 106) asserts that in the process of othering 'the fantasy of how the other lives on our account is lazy, exploits us etc is repeatedly recreated in accordance with our desire'. Doug's assertion that it is Caucasian people who pay taxes, leads to the obvious conclusion that he believes the community to comprise of non-Indigenous tax-payers who have a right to make decisions on cultural heritage and inclusion, and Indigenous nontax-payers who 'live off the system'. For Doug, the non-Indigenous names are a part of his identity, and the connection has been made to this identity through his understandings of the community around him.

As has been seen from the discussion of communities, there are groups in society which determine who is included as 'normal' and who is perceived as an 'outsider'. In this way place identity is partly formed by community definitions of inclusion and exclusion. Similarly, it can be seen that toponymic identity is partly formed through personal and community identification with particular community understandings of what is condoned as 'normal' and what is condoned as being from 'outside'. People are more likely to form an identity with toponyms which are perceived by them to be 'normal' than those which are considered 'foreign'.

\subsection{Emotions}

The previous discussion, in this paper, of inclusion and exclusion in relation to place identity leads into an exploration of what is defined as appropriate and not appropriate behaviour in a place. As posited by Manzo (2005: 83) 'the dynamics of exclusion and creating spaces of belonging have a powerful effect on people's emotional relationship to places'. Thus, within the cultural roles defined by community, the emotional effects of feeling included and excluded can play a major role in the formation of identity. Emotions, as a component of identity, assist in determining what is construed as acceptable behaviour in a place.

For Tim, an Indigenous representative who currently works in Halls Gap, the time of the proposed renaming was extremely emotional. He stated in an oral history interview that 'at the time we felt there's recognition of true ownership 
of Aboriginal people but also our identity, who we are as a people'. James, another Indigenous man who has cultural connections to the case study area, noted that he knew 'the Aboriginal community were very happy about it, about the idea. And it just gives us a bit more recognition that we're not ... a dead culture'. For Tim and James, the proposed renaming was an emotional time acknowledged by both of them, and others, to be an important step towards the wider community acknowledging and accepting Indigenous heritage in the case study area.

On the opposing side of the debate, Stawell Shire Council wrote to the Victorian Government and asserted that the proposed renaming posed 'an emotional threat to the history and heritage of descendants of original pioneers' (Lo Ricco 1989a: 36). Writers such as Florence Schulz (1990: 18) opined that 'As a child I could see the Grampians range from our kitchen window, ... and later had the misfortune to lose my mother as a result of an accident in the Grampians. I could not and will not ever accept any other names for the beauty spots there'. For Schulz the name 'Grampians' emotionally connected her to the memories she held with the area. The possibility of using other names to identify the places in the case study area was impossible because for her the proposed Indigenous names would not hold those same emotional connections.

Fred Redeker (1989) posited in a letter that it was not appropriate behaviour for the Victorian Government to propose the renaming, as it would go against mainstream values. He asserted that 'giving the land or the rights back to Aborigines and suggesting to rename places to pacify some of the stirrers ... and suggesting it is for the good and rights of the poor, exploited or displaced existing tribes ... I say baloney'. In a similar vain an anonymous writer to the Hamilton Spectator (Anon. 1989: 8) asserted that 'to force that name onto the English speaking people ... would not work... The ownership of a piece of land, or indeed the whole world, does not lie within a tribe or race that used to live there, but with the people that live there now'. For Redeker and the anonymous writer the notion of the name change occurring due to external forces outside of their community, such as the Government or Indigenous people, was anathema to their emotional understandings of what was acceptable behaviour in the case study area.

Barry noted that the decisions of what was perceived as acceptable and not acceptable in the mainstream community could be likened to the emotional reaction people feel when they have 'built a house and ... developed your garden ... you get really attached to the way it is and you don't really want to see that change. When you sell it and you move away suddenly the garden is ripped out and people completely change it and you feel really hostile against that lot'. He went on to assert that 'people don't like things not staying the way they are if they are comfortable with it'. Graham in his interview also noted that 
'people don't like change really. Well, they can accept change in small degrees but not across the board I think, it sort of throws people right out of whack and that is when the sparks flow'.

Essentially, Barry and Graham indicated that the emotional reactions the mainstream community, those in power, felt to changes was one of hostility when what they perceived to be unacceptable behaviour was occurring in their community. Their sense of ownership was visibly under threat, and the emotional reaction occurred as a voicing of perceived power being illegitimated by an action which was deemed to be out of place in the community. For a proposed name change to have this effect on a community and its inhabitants points to the notion of emotions being a component of toponymic identity.

Tuan (1991: 685) notes that 'individual words ... impart emotion and personality, and hence high visibility, to objects and places'. Similarly too, the proposal to restore Indigenous names in the case study area brought high-visibility to Indigenous heritage and according to Tuan's reasoning, the proposal brought emotional reactions. A strongly negative emotional reaction to the raising of visibility to Indigenous heritage was enunciated by Anthony Toben in a letter to the editor where he stated that

All nations have shameful skeletons tucked away in their cupboards, many of them speaking about unspeakable crimes committed against someone else. But surely ... there is nothing to be gained from digging up the smut of the past ... I would question those people's motives who continuously wish us to feel guilty about past events ... the guilt industry has us emotionally mulling in our own moral disgust ... this moral egoism, this "me and my feelings" attitude fails to offer us worthy explanations of past events. (Toben 1990: 10)

Community forces of power and control affect people's emotional reactions to change where it is perceived to be against the favour of those in power. For those who are in power, the emotional reaction is negative and can be linked to feelings of the actions being invalid and against the notions of community identity. For those who are out of power, the emotional reaction is positive and can be linked to feelings of resistance and contentment that the formerly neglected identity is being recognised.

\subsection{Events/actions}

Jedrej and Nuttal (1996: 123) assert that the landscape is a living landscape and place names are mnemonic devices that trigger recollection of particular activities'. Zerubavel (2003: 42) noted that places 'play a major role in identity rhetoric' and he proposed that events such as the hajj to Mecca, or romantic 
couples visiting the site of their first date are examples of pilgrimage which bring 'mnemonic communities into closer "contact" with their collective past'. Indeed, the contention of Zerubavel's argument is that memories of place imbue a present-day identity on the users or inhabitants of the place. This place identity is almost the glue which holds community groups together through a shared understanding of their collective past.

Chow and Healey (2008: 371) assert that 'place meaning is in part created and confirmed through in-place-experiences' and as such it could be argued following the previous analysis in this paper that the experiences which create place also create names. Thus, experiences which brought about the original and then subsequent renaming of places in the case study area could be said to have brought meaning and therefore identity to the people who associate with the area. The ongoing maintenance of the names from 1836 until 1989-1990 led to the confirmation of perceptions of community power, inclusion and exclusion.

The experiences which are deemed to be important by a community are memorialised in various ways. Similarly to the arguments posited by Zerubavel, Lewicka (2008: 214) posits that 'places remember and they do it though their monuments, architectural style of their buildings, inscriptions on walls etc. For people who reside there, the traces play the function of "urban reminders", the "mnemonic aids" to collective memory'. The decision on which monuments are erected and which events are memorialised is a constant battle between those included in the community and those excluded from it. I would argue that based on the research data analysed so far in this paper, that in a way similar to buildings and inscriptions on walls, events and actions are remembered by placenames. In this way, in their memorialisation of actions and events, communities utilise toponyms as mnemonic devices for their collective identity.

\section{Conclusion}

As stated in the introduction to this paper, the intention was to create a theory (or theories) of the constitution of toponymic identity. Place identity is an emotional function of place attachment (Sharpe and Ewert 2000) and is linked to the symbolic nature of place relationships (Williams and Vaske 2003). In addition, the formation of place identity can dictate within a community what actions should occur in a place and how people should behave within a particular setting (Proshansky, Fabian and Kaminoff 1983).

It was seen that personal and community identity can be tied to a toponym(s) in a similar way to which it can be linked to places. The discussion in part focused on the power dynamics of place inclusion and exclusion exhibited by communities. It was argued that the existence of non-Indigenous names in the 
Indigenous and Minority Placenames

landscape served as constant reminders of colonial history and 'ownership' of the landscape. It was this colonial history that many opponents of the name change supported, as they argued that removal of non-Indigenous names would remove their emotional connections to colonial history and sense of community. Concomitantly, those in the community who identified with the Indigenous names were jubilant at the proposal because they believed it to be an acceptance of Indigenous identity in the case study area, and they connected with the Indigenous names. Thus, it was argued that toponymic identity can exist in a similar way to place identity, with a distinction being made because the connections to history and community by the participants was linked strongly to the names rather than the places themselves. Obviously, the constructs of place and toponymic identity are strongly correlated, as places would not exist without names, and names would have no purpose without places.

\section{References}

Albrecht, M 1990, 'Grampians', The Wimmera Mail-Times, 8 August 1990: 18.

Anon. 1989, 'Not a racist', Hamilton Spectator, 24 June 1989: 8.

Baker, R. 1999, 'Land is life: a cultural geography of australian contact history', in Australian Cultural Geographies, Elaine Stratford (ed.), Oxford University Press, South Melbourne: 25-47.

Beale, E. 1989, 'Name change "clap trap"', Hamilton Spectator, 1 April 1989.

Carter, E., J. Donald and J. Squires (eds) 1993, Space and Place: Theories of Identity and Location, Lawrence \& Wishart, London.

Chow, K. and M. Healey 2008, 'Place attachment and place identity: first-year university undergraduates making the transition from home to university', Journal of Environmental Psychology 28: 362-372.

Churton, F.R. 1990, 'Risky business, native names', The Sun, 7 June 1990: 59.

Crane, S. 1997, 'Writing the individual back into collective memory', The American Historical Review 102(5): 1372-1385.

Cresswell, T. 2004, Place: A Short Introduction, Blackwell Publishing, Melbourne.

Crozier, D. 1989, 'Bugara Off, Mr Crabb!', Hamilton Spectator, 1 April 1989.

Dadswell, K.W. 1989, 'Stand on Grampians name "arrogance"”, Stawell TimesNews, 14 April 1989. 
Day, V. 1990, 'Appalled at name change proposal', Stawell Times-News, 17 July 1990: 2.

Editor 1989, 'Council of Clans and an elderly woman object to name change', The Age, 12 May 1989.

Fitzsimmons, J. 1989, 'Crabb's audacity in renaming mountains must be opposed', The Age, 30 March 1989: 12.

Fraser, J. 2005, The Roman Conquest of Scotland: The Battle of Mons Graupius AD84, Tempus, Gloucestershire.

Furniss, E. 2001, 'Timeline history and the Anzac myth: settler narratives of local history in a North Australian town', Oceania 71(4): 279-298.

Golding, E. 1990, 'Mulga not tinkit fit', Warracknabeal Herald, 10 July 1990: 8.

Henry, B. 1990, 'Name changes show justice to Aborigines', The Age, 18 August 1990: 10.

Hernandez, B., C. Hidalgo, M. E. Salazar-Laplace and S. Hess 2007, ‘Place attachment and identity in natives and non-natives', Journal of Environmental Psychology 27: 310-319.

Hey, C. and D. 1990, 'Grampians and "local" blacks', The Sun, 22 June 1990: 37.

Hidalgo, C. and B. Hernandez 2001, 'Place attachment: conceptual and empirical questions', Journal of Environmental Psychology 21: 273-281.

Hoelscher, S. and D. Alderman 2004, 'Memory and place: geographies of a critical relationship', Social and Cultural Geography 5(3): 347-355.

Jackson, P. 1989, Maps of Meaning: An Introduction to Cultural Geography, Unwin Hyman, London.

Jedrej, C. and M. Nuttall 1996, White Settlers: The Impact of Rural Repopulation in Scotland, Penguin Press, Luxembourg.

Johnson, C. 1990, 'Crabb must go', The Wimmera Mail-Times, 8 June 1990: 17.

Jorgensen, B. and R. Stedman 2006, 'A comparative analysis of predictors of sense of place dimensions: attachment to, dependence on, and identification with lakeshore properties', Journal of Environmental Management 79: 316-327.

Kostanski, L. 2009, “"What's in a Name?": Place and Toponymic Attachment, Identity and Dependence. A case study of the Grampians (Gariwerd) National Park name restoration process', PhD Thesis, School of Business, University of Ballarat, Ballarat (Australia). 
Indigenous and Minority Placenames

Levi-Strauss, C. 1962, The Savage Mind, University of Chicago Press, Chicago.

Lewicka, M. 2008, 'Place attachment, place identity and place memory: restoring the forgotten city past', Journal of Environmental Psychology 28: 209-231.

Lo Ricco, R. 1989a, 'Grampians name change', The South Gippsland SentinelTimes, 14 June 1989: 36.

Lo Ricco, R. 1989b, 'Grampians name change debate', The Colac Herald, 2 June 1989: 7.

Lowenthal, D. 1997, The Past is a Foreign Country, Cambridge University Press, Cambridge.

Manzo, L. 2005, 'For better or worse: exploring multiple dimensions of place meaning', Journal of Environmental Psychology 25: 67-86.

Patterson, M. and D. Williams 2005, 'Maintaining research traditions on place: diversity of thought and scientific progress', Journal of Environmental Psychology 25: 361-80.

Penrose, J. and P. Jackson (eds) 1994, Constructions of Race, Place and Nation, University of Minnesota Press, Minnesota.

Pietsch, A. 1990a, 'What's in a name?', The Weekly Times, 8 August 1990: 12.

Pietsch, R. 1990b, 'Letter from Names Committee', Ararat Advertiser, 25 August 1990: 10 .

Pretty, G., H. Chipuer and P. Bramston 2003, 'Sense of place amongst adolescents and adults in two rural Australian towns: The discriminating features of place attachment, sense of community and place dependence in relation to place identity', Journal of Environmental Psychology 23(3): 273-287.

Proshansky, H. 1978, 'The city and self-identity', Environment and Behaviour 10: $147-169$.

Proshansky, H., A. Fabian and R. Kaminoff 1983, 'Place identity: physical world socialisation of the self', Journal of Environmental Psychology 3: 57-83.

Ramsay, G. 2003, 'Cherbourg's Chinatown: creating an identity of place on an Australian Aboriginal settlement', Journal of Historical Geography 29(1): 109-122.

Redeker, M. F. 1989, 'Stirrers', Wimmera Mail-Times, 5 April 1989. 
Salecl, R. 1993, 'National identity and socialist moral majority', in Space \& Place: Theories of identity and location, Erica Carter, James Donald and Judith Squires (eds), Lawrence \& Wishart, London: 101-111.

Schulz, F. 1990, 'Renaming horrifies', The Wimmera Mail-Times, 8 June 1990: 18.

Seddon, G. 1997, 'Words and weeds: some notes on language and landscape', in Landprints: Reflections on Place and Landscape, George Seddon (ed.), Cambridge University Press, Cambridge: 15-27.

Shamai, S. 1991, 'Sense of place: an empirical measurement', Geoforum 22(3): 347-358.

Sharpe, E. and A. Ewert 2000, Interferences in Place Attachment: Implications for Wilderness, www.wilderness.net/library/documents/Sharpe_3-29.pdf.

Shumaker, S. and R. Taylor 1983, 'Toward a clarification of people-place relationships: a model of attachment to place', in Environmental psychology: Directions and Perspectives, N. Feimer and E. Gell (eds), University Press, New York: 219-251.

Taylor, C. 1992, 'The politics of recognition', in Multiculturalisam, ed. Amy Gutman (ed.), Princeton University Press, Princeton: 25-73.

Toben, Dr A. 1990, 'Guilt industry', The Wimmera Mail-Times, 13 July 1990: 10.

Tuan, Y.-F. 1991, ',Language and the making of place: a narrative-descriptive approach', Annals of the Association of American Geographers 81(4): 684-696.

Twigger-Ross, C. and D. Uzzell 1996, 'Place and identity processes', Journal of Environmental Psychology 16(3): 205-220.

UNGEGN 2007, Report of the UNGEGN Working Group on the Promotion of Indigenous and Minority Group Place Names, United Nations, New York.

White, D., R. Virden and C. van Riper 2008, 'Effects of place identity, place dependence, and experience-use history on perceptions of recreation impacts in a natural setting', Environmental Management 42: 647-657.

Williams, D. and J. Vaske 2003, 'The measurement of place attachment: validity and generalizability of a psychometric approach', Forest Science 49(6): 830-840.

- 2004, The Measurement of Place attachment: Validity and Generalizability of a psychometric approach, 2002 [cited March 2004]. Available from www.fs.fed. us/rm/value/docs/psychometric_place_attachment_measurement.pdf. 
Indigenous and Minority Placenames

Withers, C. 2000, 'Authorizing landscape: "authority", naming and the Ordnance Survey's mapping of the Scottish Highlands in the nineteenth century', Journal of Historical Geography 26(4): 532-554.

Wong, J. 2002, 'What's in a name? An examination of social identities', Journal for the Theory of Social Behaviour 32(4): 451-463.

Zerubavel, E. 2003, Time Maps: Collective Memory and the Social Shape of the Past, University of Chicago Press, Chicago. 
This text taken from Indigenous and Minority Placenames: Australian and International Perspectives, Edited by Ian D. Clark, Luise Hercus and Laura Kostanski, published 2014 by ANU Press, The Australian National University, Canberra, Australia. 